YEARBOOK

of ANTITRUST

and REGULATORY

STUDIES

www.yars.wz.uw.edu.pl
Peer-reviewed scientific periodical, focusing on legal and economic issues of antitrust and regulation. Creative Commons Attribution-No Derivative Works 3.0 Poland License.

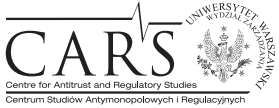

Centre for Antitrust and Regulatory Studies, University of Warsaw, Faculty of Management www.cars.wZ.uw.edu.pl

\title{
To Regulate Or Not to Regulate? - Economic Approach to Indefeasible Right of Use (IRU)
}

\author{
by
}

Magdalena Olender-Skorek*

\section{CONTENTS}

I. Introduction

II. Theoretical background

III. Practical background

IV. Game theory model for Indefeasible Right of Use - economics approach

1. IRU definition

2. Model assumptions

3. Strategic behaviours

4. The results

V. Problems and Conclusions

\section{Abstract}

The aim of this paper is to present an Indefeasible Right of Use (IRU) as a possible remedy for telecom infrastructure EU projects that (in Poland) have been lagged behind the time. Thanks for IRU, Beneficiaries of these EU projects will be able to save both: time and money and will finish projects successfully. The author discusses two possible methods of implementing IRU: via regulatory obligation and via incumbent's goodwill. The author proposes a game theory model with payoffs depending on regulator's and incumbent's strategies. Using a game theory tree, the author shows that if only the incumbent is willing to offer his own network, IRU may be signed and most delays in EU projects disappear. The success is not so obvious while implementing IRU as an obligation - in this case EU projects will probably fail.

* Magdalena Olender-Skorek - Assistant Professor, at Faculty of Management, University of Warsaw. 


\section{Résumé}

Le but de cet article est de présenter le droit irrévocable d'usage (IRU) comme un remède possible pour les projets d'infrastructure de télécommunications de l'UE qui, en Pologne, ont été lancés avec du retard. Grâce à l'IRU, les bénéficiaires de ces projets européens seront en mesure d'épargner à la fois le temps et l'argent pour terminer des projects avec succès. L'auteur décrit deux méthodes possibles de mise en œuvre de l'IRU: par l'obligation réglementaire et par le bias de bonne fois de l'opérateur historique. Lauteur propose un modèle de la théorie des jeux avec des gains qui dépendra de la stratégie choisie par le législateur et par l'opérateur historique. Par l'utilisation d'un arbre de la théorie des jeux, l'auteur montre que si seulement l'opérateur historique est prêt à offrir son propre réseau, l'IRU peut être signé, ce qui en effet aboutira à la disparition de la plupart des retards dans la mise en oeuvre des projets. Le succès n'est pas si évident dans le cas où la mise en œuvre de l'IRU est une obligation - là, les projets européens échoueront probablement.

Classifications and key words: Indefeasible Right of Use (IRU); long-term agreement; third party access; telecom market; entry barriers; infrastructure owner; entrants; infrastructure; EU projects.

\section{Introduction}

The telecommunications market is one of the fastest-growing in the economy nowadays. The expansion of ICT will continue since knowledge and information flow are crucial for competitive advantages. Still, in many countries such as Poland there is a bottleneck in the telecom market: entry barriers. These have caused problems with quality and accessibility to infrastructure as well as with upgrades and investment.

The aim of this article is to analyze a new remedy for entry barriers - an Indefeasible Right of Use (IRU). IRU is a long-term agreement between infrastructure owners and newcomers. Although it is similar to leased lines and other third party access mechanisms, it is a better substitute to building a new network than the two aforementioned solutions (the licensee is treated as an owner of infrastructure, usually with amortizsation rights).

An Indefeasible Right of Use may be imposed as a regulatory tool or as a good will gesture of the incumbent. This article focuses on this aspect providing a voice in the debate on whether to regulate IRU or not. The first part presents the applicable theoretical background. As mentioned, the main problem with infrastructure investments and the development of competition in telecoms are entry barriers. A taxonomy of entry barriers in light of existing 
economics literature is presented next and crucial entry barriers related to the use of IRU identified.

The second part of the article contains practical aspects of entry barriers. Many instruments have already been used in order to handle them: third party access, wholesale price regulation, improving the investment process and public aid. Even the European Union has provided funds for telecom infrastructure building and modernization. The problem is how to spend these EU funds properly and achieve from then the biggest possible added value. Few regulatory tools similar to IRU were presented with entry barriers they were to fight with.

The next part of the paper is devoted strictly to IRU. Differences between IRU and previous regulatory tools, setting up IRU prices and challenges in implementing IRU are stressed. A game theory model is presented next to show different results depending on the methodology used of IRU implementation (by regulatory obligation or by choice of the incumbent). The assumptions of such a model are key here and thus they are described in detail. The analysis and assumptions applied in this paper are all coherent with the Polish telecoms market and Polish experiences. The Polish example is visible in problems with infrastructure investments, spending EU funds and documents prepared by polish regulatory authority, but it does not mean that the paper is not useful for other country.

The article closes with a resolution of the game theory model. It leads to the conclusion that IRU may improve the level of infrastructure investments, but only under certain circumstances.

\section{Theoretical background}

The concept of Indefeasible Right of Use (hereafter, IRU) is based on a theoretical problem called entry barriers. Entry barriers differ in their origins: some are caused by legal measures, some derive from behavioral issues and others have an economic background. A taxonomy of entry barriers, under economics literature studies, is shown below:

1) legal entry barriers - appear only as an effect of law restrictions and may be characterized by asymmetric treatment of market players (the rules are in favor of enterprises that were given an exclusive right to run a business); they are the most volatile and unstable of all entry barriers: they may be cancelled with a regulatory decision; common examples are: licenses, quality service obligations (formal standards), and patents;

2) behavioral entry barriers - are considered to exist wherever one firm tries to abuse its market power (and fights with competitors in an 
uncompetitive way); these barriers are not as easy to eliminate as legal ones, but may be limited by the imposition of new regulatory obligations (dedicated to significant market power enterprises); examples are usually: mobility costs, localization, experience and asymmetric information, and price reactions to entry attempts;

3) technological barriers - are linked with the specifics of a given sector, type of activity, cost structure and difficulties resulting from historical reasons; they are constant, steady and hard to remove by regulation; most popular examples are: cost advantages, sunk costs, capital restrictions, timeconsuming startup of a business, uncertainty and asymmetric information.

IRU is most relevant to economic entry barriers. An overview of literature made it possible to summarize certain theories in Table 1, where each mentioned economic author treats different factors as entry barriers. Aside from their division, there is little consensus about counting each economic factor as a barrier. Herein, the assumption is made that a barrier is anything that literature has ever considered as such.

Table 1. A set of factors treated as entry barriers in different economic theories (chronological order)

\begin{tabular}{|c|c|c|c|c|c|c|}
\hline \multirow[b]{2}{*}{ Author ${ }^{1}$} & \multicolumn{6}{|c|}{ Factor } \\
\hline & $\begin{array}{l}\text { Scale } \\
\text { effect }\end{array}$ & $\begin{array}{c}\text { Product } \\
\text { differentia- } \\
\text { tion }\end{array}$ & $\begin{array}{c}\text { Cost } \\
\text { advantage }\end{array}$ & $\begin{array}{c}\text { Capital } \\
\text { require- } \\
\text { ments }^{2}\end{array}$ & $\begin{array}{l}\text { Time-con- } \\
\text { suming }\end{array}$ & Uncertainty \\
\hline \multicolumn{7}{|l|}{ Bain } \\
\hline \multicolumn{7}{|l|}{ Stigler } \\
\hline \multicolumn{7}{|l|}{ Caves/Porter } \\
\hline \multicolumn{7}{|l|}{ Gilbert } \\
\hline \multicolumn{7}{|l|}{ Noga } \\
\hline \multicolumn{7}{|c|}{ Carlton/Perloff } \\
\hline \multicolumn{7}{|c|}{$\begin{array}{l}\text { McAfee/Mialon/ } \\
\text { Williams }\end{array}$} \\
\hline \multicolumn{7}{|l|}{ Schmalensee } \\
\hline \multicolumn{7}{|l|}{ Pindyck } \\
\hline Carlton & & & & & & \\
\hline
\end{tabular}

Source: Author's own studies

1 Bain (1956), Stigler (1968), Caves/Porter (1977), Fisher (1979), Weizacker (1980), Gilbert (1989), Schmalensee (1981, 2004), Noga (1993), Carlton/Perloff (1994), McAfee/Mialon/ Williams (2004), Pindyck (2005), Carlton (2005).

2 The table presents 'capital requirements' together with 'sunk costs'. 
Among factors listed in table 1, only product differentiation is distanced from IRU. The rest are linked to IRU, either directly or indirectly. Especially capital requirements and time-consuming activities are factors IRU is believed to remedy. The reasoning on the link between the IRU (or other third party access tools) and entry barriers was always well analyzed by the polish regulatory body or by researches conducted by experts ${ }^{3}$. What is both clear and obvious here is that if a new entrant has no infrastructure, it needs to build it. Network design, research of local conditions and finally construction are costly and time consuming. Entering the market simultaneously alerts the incumbent of the emergence of a new competitor. Delay means more time for an incumbent to prepare a strategy to fight against the new competitor. In this case the entrant has no chance. What a regulatory body usually does, is to ensure a fast and effective entry - usually by granting fair access to the incumbent's existing infrastructure.

\section{Practical background}

The telecommunication market has been trying to solve issues related to entry barriers for years. Many activities have already been undertaken to remove this bottleneck. Privatisation, third party access and quality or price regulation were the most popular and effective types of regulation. It is suggested by other world's examples, where the situation was changed after the incumbent's privatization. Most of them are asymmetric, imposing an obligation only upon the incumbent enterprise, giving free choice to its competitors. That is why it is crucial to set payments carefully and make an honest cost-benefit analysis.

Product differentiation in the telecoms market is only a marketing matter. If networks look the same and technology and technical standards are the same, there is no place to compete through product differentiation. The only way to compete is creating different bundles of services, different prices and level of post-sale service.

Cost advantages come from amortization and scope effects. An incumbent has obviously the biggest client database, access to the best market research and most experience. That is why it is not a problem for an incumbent to proceed in the cheapest and yet effective way - provided there is an impulse to do so. It is hard to regulate and remove this barrier and treat the incumbent in a fair way compared to new entrants. In this case, a regulatory body usually

3 To get detailed information please see The analysis of TP's functional separation, UKE 2008; The regulatory strategy for telecom market in years 2008-2012, UKE, Warsaw 2008. 
concentrates on improving newcomers' financial prospects, by setting pricecost obligations whereby each fee should be based on a reasonable cost of services. Regulatory accounting obligations have a similar aim.

Crucial for entry barriers are those telecom regulations that relate to third party access. Wholesale line rental (WLR), Bitstream Access (BSA) and Local Loop Unbundling (LLU) are the most popular ones which impose upon the incumbent an obligation to make its network accessible. The aforementioned tools differ as to the level of access to the incumbent's network, the type of technology and the range of retail services that the entrants can provide. In all cases the regulator sets (or at least accepts) access prices. Actually, WRL, BSA and LLU are very similar to IRU, as far as IRU is a long-lasting access obligation.

Capital requirements have been solved lately with EU funds. A variety of activities that can be funded through EU resources gives the newcomers the opportunity to build their own networks even in unattractive areas, i.e. areas with low population density. It does not mean that European Union is wasteful and spends its money in inappropriate way. The primary EU's aim is to prevent social exclusion and it is more important than business profitability ${ }^{4}$. The EU is willing to help in telecom infrastructure development. Through different countries' institutions, it helps in exchanging experience between EU projects Beneficiaries (in Poland the most of Beneficiaries are municipal authorities),

Table 2. Regulations and their influence on entry barriers

\begin{tabular}{|l|l|l|l|c|c|c|}
\hline \multirow{2}{*}{ Regulation } & \multicolumn{5}{|c|}{ Entry barrier } \\
\cline { 2 - 6 } & $\begin{array}{c}\text { Scale } \\
\text { effect }\end{array}$ & $\begin{array}{c}\text { Product } \\
\text { differen- } \\
\text { tiation }\end{array}$ & $\begin{array}{c}\text { Cost } \\
\text { advantage }\end{array}$ & $\begin{array}{c}\text { Capital } \\
\text { require- } \\
\text { ments }\end{array}$ & $\begin{array}{c}\text { Time-con- } \\
\text { suming }\end{array}$ & $\begin{array}{c}\text { Uncertainty } \\
\text { (with asymmetric } \\
\text { information) }\end{array}$ \\
\hline Quality regulation & & & & & & \\
\hline Price regulation & & & & & & \\
\hline Accountant regulation & & & & & & \\
\hline Price-cost relationship & & & & & & \\
\hline $\begin{array}{l}\text { Third Party Access } \\
\text { (WLR, BSA, LLU) }\end{array}$ & & & & & & \\
\hline EU funds & & & & & & \\
\hline IRU & & & & & & \\
\hline
\end{tabular}

$\square$ - the regulation affects a certain entry barrier - the regulation does not affect an entry barrier

Source: Author's own studies based on: W. Borucki, K. Bielewicz, P. Radziulis, The Relevance Analysis of implementing WLR in Poland, Instytut Technik Telekomunikacyjnych i Informatycznych, Poznań 2005, UKE Market reports and P.Bijl, M Peitz, Regulation and Entry into Telecommunication Markets, 2004.

${ }^{4}$ For more information see Digital Agenda for Europe (European Commission, 2010). 
improves qualifications by way of courses and training, and controls schedules and funding. The one thing the EU is not able to control is investment process just because the lack and the lag of information about real progress of projects' realization. This variable seems to be crucial for infrastructure build-out.

Table 2 is a summary of the considerations presented above.

\section{Game theory model for Indefeasible Right of Use - economics approach}

\section{IRU definition}

Talking about IRU and infrastructure investments may flow in different ways. The way of thinking about the subject is determined by definitions. The first question to ask is what does IRU stand for? This article treats IRU as an agreement between the infrastructure owner and the telecoms enterprise interested in leasing it on a long-term basis. The IRU user can unconditionally and exclusively use some part of the telecom network (usually optical fibres) for about 20 years. From an accounting point of view, the user of infrastructure is treated as the network owner. Depending on the type of IRU agreement, it can be treated as a leasing, usufruct or right familiar to financial leasing. The type of IRU agreement used has its implications for cost eligibility. Herein a simplification is made whereby IRU expenditure is an eligible cost in all cases. It means that the beneficiaries of EU projects can always get back the money that they have spent.

Payment for IRU is typically divided into two parts:

- lump sum (also called balloon amount) - the greatest part of the IRU budget that is paid at the beginning of the IRU period; it should correspond to infrastructure costs;

- periodic fee - paid every month or year, not budget consuming; should be calculated taking into account the inflation rate, economic fluctuations, plus infrastructure upgrades and maintenance of IRU services.

IRU is usually treated as a co-investment solution to build joint infrastructure. Typically co-investors are an incumbent operator (infrastructure owner) and a state-owned shareholder (including municipal agencies). It provides a huge benefit when considering inefficient duplication of infrastructure, the time consuming investment process or problems with financing a new network. But under these great sounding phrases, IRU generates many problems, mainly because of future uncertainty. Businesses participated in the IRU should take into account: What if the infrastructure grantor goes bankrupt? What 
if he loses its 'significant market power'? How is the proper value of IRU calculated? What about infrastructure upgrades and new technologies? Who should bear the risk of a long-lasting contract? And policy-makers should keep in mind: Is it an appropriate way of stimulating competition? Is it really helpful for EU projects?

\section{Model assumptions}

The important question is thus: should IRU be regulated or not? In other words: what effects would these two alternatives generate (regulated or nonregulated IRU)? This problem is analyzed using game theory.

A few assumptions are made here for the model of the consequences of IRU.

1. First, the main aim is to spend EU funds on time by building telecoms infrastructure wherever there is a lack thereof. Thinking this way makes it possible to formalize the following statement: investments should proceed fast, as beneficiaries have only 3 years to finish their projects. Beneficiaries should also make their investments cost-effectively otherwise they won't get their expenditure reimbursed by the EU.

2. The second assumption is about players. 3 main actors exist here: an infrastructure owner (typically an incumbent), the EU funds Beneficiary (the public sector who is actually an executor of an EU project ${ }^{5}$ ) and the regulator. The first wants to maximize its profits. Moreover, it obstructs the fulfillment of all obligations that the regulator imposes upon it. Threatened by a new obligation, the incumbent will try to hold it off by spending money to postpone the arrival of regulation. As a result, the EU-funded project fails - the infrastructure is built too late. This is a catastrophe, because the EU won't reimburse the project and the aim of building the infrastructure won't be achieved. The second actor, the Beneficiary, has its own goal: to finish the project on time because it's the only way to get its costs reimbursed. Its success is determined only by the time of the IRU offer. If the facilities owner is ready to sign an IRU contract on time, the Beneficiary will finish its project. Otherwise, it won't. The third actor, the regulator, wants to maximize social benefit no matter which of the other actors it will support. That is why the regulator should take into account the costs of failed projects as well as the costs of regulation and make a regulatory impact assessment before acting.

5 There are some projects leading by private sector units but most of EU telecom infrastructure projects are executed by municipal authorities or by public-private partnerships. 
3. The third assumption is about payoffs - the costs of regulation and IRU delays (this is why only half of EU projects are successful). Additionally, regulation is usually accompanied by a loss of flexibility. It diminishes the incumbent's profit gained from IRU. In payoffs, certain factors are taken into account, fulfilling the following assumptions:

- $\Pi_{\mathrm{B}}>0-$ Beneficiaries' profits is higher than zero;

- $\Pi_{\mathrm{BE}}>0$ - Beneficiaries' fines in case of failed of EU projects they lead;

- $\Pi_{p}>0$ - incumbent's profit in optimistic scenario is positive (more than zero);

- $\Pi_{\mathrm{n}}<0$ - incumbent's profit in pessimistic scenario is negative (less than zero);

- $\mathrm{C}_{\mathrm{R}}>0$ - cost of IRU regulation;

- $\mathrm{C}_{\mathrm{O}}>0$ - cost of incumbent's opportunity behaviour;

- $\varepsilon>0-$ cost of the lack of elasticity, caused by regulatory obligation;

- $0.5^{*} \Pi_{\mathrm{n}}+\mathrm{C}_{\mathrm{O}}<0-$ cost of incumbent's opportunity behavior is less than the loss of pessimistic scenario.

4. The last assumption is about the uncertainty included in the model. There are two options:

- optimistic (market will develop well and IRU will generate profit),

- pessimistic (market will not develop as one should expect and IRU will generate a loss).

\section{Strategic behaviours}

A set of strategies is dedicated only to the regulator (government) and infrastructure owner. The regulatory body may impose an IRU regulation or let the actors act in a spontaneous way. This means that IRU may be chosen as a regulatory tool, may be launched by the incumbent according to its own rules or may not happen at all. The incumbent may be willing to sign the IRU contract or it might not. If it is not happy to sign the contract, it will try to delay the imposition of IRU. The EU funds Beneficiary has no choice in this game scenario - it can only deal with the results of the actions of the other two players. Still, the regulator's interest takes into account the Beneficiary's goals.

The regulator is first to make a choice as it is the one who sets the rules. Unfortunately, there is a lack of information: no one knows the future and no one is able to say whether in 20-25 years (at the end of the IRU contract) the situation will be positive (optimistic option) or negative (pessimistic option). The uncertainty of the game is taken into account with the 4th assumption of the model.

The optimistic option, from the infrastructure owner's point of view, means it will gain positive result (above zero): profits denoted as $\Pi_{p}$. The pessimistic 
option means that the incumbent's profits will be negative (below zero) denoted as $\Pi_{\mathrm{n}}$.

Moreover, implementation of regulation always takes time: the regulator needs to analyze the market, prepare a proper regulatory act, conduct a public consultation, analyze all comments and make a cost-benefit analysis. This means that only some infrastructure projects will be finished successfully (those with the biggest delays will not). In the payoff, it is denoted as $0.5^{*} \Pi_{\mathrm{B}}$ (half of all EU funds that are able to be reimbursed). IRU without regulatory intervention gives all EU funds: $\Pi_{B}$, because in this case all projects will be finished successfully. Figure 1 shows the game tree representation of the payoffs (also known as the extensive form representation).

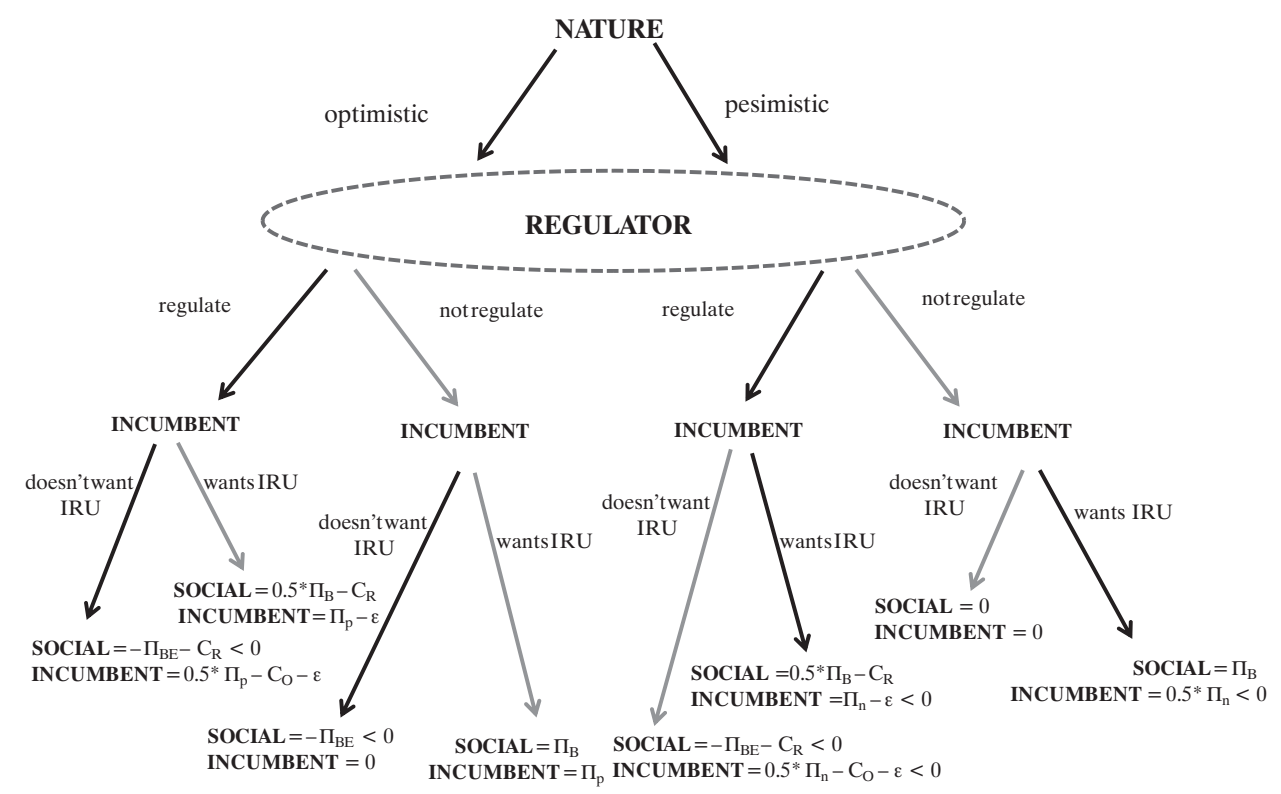

Figure 1. An extensive version of the IRU model

\section{The results}

In the game theory tree (Figure 1) eight different results are visible. Suppose the game is played with the optimistic option. The regulator decides to regulate IRU or not and it chooses the first possibility: regulated IRU. The next step belongs to the facilities owner (the incumbent) that may behave obstructively to signing an IRU agreement or not. Suppose it will also choose 
the first option. What is the result? From the regulator's point of view we have a double delay: one caused by the implementation of the regulation and the second caused by the delay tactics of the incumbent. Because of this, several EU projects fail and Beneficiaries lose all incurred expenditure. The EU will punish the Beneficiary with a quota denoted as $-\Pi_{\mathrm{BE}}$. The negative sign of profit shows that (in the above scenario) it was better not to start the EU project at all. The amount will be diminished by the cost of regulation $\left(C_{R}\right)$. What about the incumbent? It behaves obstructively so effectively that it manages to block the implementation of the IRU obligation. That is why it 'earns' 0 from IRU contracts, but because of its obstructive effort, $\mathrm{C}_{\mathrm{O}}$ will not be saved. From the incumbent's point of view, the payoff with regulation is worse than without regulation, i.e. as a loss of elasticity, which is denoted as $\varepsilon$. The incumbent, however, stayed away from the IRU contract, so it loses $-\left(\mathrm{C}_{\mathrm{O}}+\varepsilon\right)$.

Supposing now that the incumbent is willing to sign the IRU contract (in accordance with the regulator's orders and the optimistic option). Other previous assumptions are ceteris paribus. The change in its payoff is obvious: now it will earn $\Pi_{p}$ from IRU minus $\varepsilon$. The incumbent is not against regulation, and will not bear the obstruction $\operatorname{cost} \mathrm{C}_{\mathrm{O}}$. From a social (or regulatory) point of view, half of the projects end successfully: $0,5 * \Pi_{\mathrm{B}}$, minus the costs of regulation: $C_{R}$. In this case, using a backward induction points out that if only the IRU is regulated, the infrastructure owner will choose to sign an IRU contract - it prefers $\Pi_{p}-\varepsilon>0$ to $0-C_{O}-\varepsilon<0$ provided the incumbent proceeds in a rational way.

Staying with the optimistic variant, let's suppose that the regulatory body chooses not to regulate IRU. There are no regulation costs $C_{R}$ and elasticity costs $\varepsilon$. The incumbent may still behave in the same way: either sign the IRU contract or not. The final results are as follows:

- the incumbent doesn't sign an IRU contract:

$\checkmark$ no project succeeds, so social result equals $-\Pi_{\mathrm{BE}}$;

$\checkmark$ the incumbent has no agreement and earns 0 ;

- the incumbent signs an IRU contract:

$\checkmark$ all projects succeed, social result equals $\Pi_{B}$;

$\checkmark$ the incumbent earns $\Pi_{\mathrm{p}}$

The pessimistic option will proceed similarly, as can be seen in Figure 1. The game theory model (with the above assumptions, strategies and aims) suggests the conclusion that irrespective of external circumstances (in other words, irrespective of a 'Nature' factor), there is no justification for implementing IRU through a regulatory path. Rationality alone will lead an incumbent to choose an IRU agreement in the most efficient way. If the regulator comes into action, an incumbent will become opportunistic and delay IRU. This 
is why, if IRU is to support EU funds, it should be left out of the ambit of regulatory obligations. Otherwise, most of delayed EU projects are going to fail.

\section{Problems and conclusions}

There are some limitations in above game theory model. First of all it ignores some behavioural aspects as blocking IRU and blocking market entries, using cross subsidy and gaining higher incumbent's profits because of the lack of competition. It may be developed in a further and more detailed research. The analysis may also be developed with other countries cases. Although these obvious limitations, the presented model is not unrealistic as far as polish telecom market review seems to be constant. First of all, Polish incumbent is interested in long-term agreements. The argument is Polish incumbent's involvement in preparing IRU offer (the half of the year 2012), preliminary negotiations with some of these EU projects' Beneficiaries, consulting these works with external advisors ${ }^{6}$. The second mentioned limitation (using cross subsidy) is illegal from competition law point of view. The incumbent may gain higher profits but (as a significant market power) it will probably have to pay huge fine for it (so it is not worth).

\section{Literature}

Bain J. S., Barriers to New competition: their character and consequences in manufacturing industries, Harvard University Press, 1956.

Bijl P., Peitz M., Regulation and Entry into Telecommunication Markets, Cambridge 2004.

Borucki W., Bielewicz K., Radziulis P., The Relevance Analysis of implementing WLR in Poland [Analiza zasadności wdrożenia WLR w Polsce], Instytut Technik Telekomunikacyjnych i Informatycznych, Poznań 2005.

Bourreau M., Doğan P., „Build-or-Buy” Strategies in the Local Loop’ (2006) 96(2) The American Economic Review.

Carlton D.W., Barriers to Entry, NBER Working Papers 11645, National Bureau of Economic Research, Inc., 2005.

Cave M., Majumdar S.K., Vogelsang I., Handbook of Telecommunications Economics. Structure, Regulation and Competition, vol. 1, Elsevier, 2002.

${ }^{6}$ Referrence Offer for Infrastructure, TP, 2012, consultations with experts from National Institute of Telecommunications, business talks with municipal. 
Caves R.E., Porter M.E., 'From Entry Barriers to Mobility Barriers: Conjectural Decisions and Contrived Deterrence to New Competition' (1977) 91(2) The Quarterly Journal of Economics.

BEREC Report on Co-investment and SMP in NGA Networks, 2011.

Fisher F.M., 'Diagnosing Monopoly' (1979) 19(2) Quarterly Review of Economics and Business.

Guthrie G., 'Regulating Infrastructure: The Impact on Risk and Investment' (2006) 44(4) Journal of Economic Literature/

Laffont J.J., Tirole J., Competition in telecommunications, The MIT Press, 2000.

McAfee R.P., Mialon H.M., Williams M.A., What Is a Barrier to Entry?, The American Economic Review, Vol. 94, nr 2, Papers and Proceedings of the One Hundred Sixteenth Annual Meeting of the American Economic Assocation San Diego, CA, 2004.

Noga A., Dominacja a efektywna konkurencja, Fundacja Naukowa Taylora, Warszawa 1993.

Pindyck R. S., Sunk Costs and Real Options in Antitrust, NBER Working Papers 11430, National Bureau Of Economic Research, Inc., 2005.

Pindyck R. S., Sunk Costs and Risk-Based Barriers to Entry, NBER Working Papers 14755, National Bureau of Economic Research, Inc., 2009.

Porter M. E., Competitive Strategy: Techniques for Analyzing Industries and Competitors, The Free Press, New York 1980.

Public consultation on the IRU Reference Offer, UKE, document of public consultation, 2012 Refference offer for infrastructure, Telekomunikacja Polska, 2012.

Response to the public consultation on the IRU Reference Offer, UKE, Warszawa 2012.

Response to the public consultation on costing methodologies for key wholesale access prices in electronic communications, Bouygues, public consultations, 2011.

Schmalensee R., 'Economies of Scale and Barriers of Entry' (1981) 8(6) Journal of Political Economy.

Schmalensee R., 'Sunk Costs and Antitrust Barriers to Entry' (2004) 94(2) American Economic Review.

Stigler G., The organization of industry, University of Chicago Press, 1968.

von Weizäcker C., 'A welfare Analysis of Barriers to Entry' (1980) 11 Bell Journal of Economics.

The explanatory note about eligibleness of telecom infrastructure leasing costs (including IRU), according to Development of Eastern Poland and Regional Operational Programmes, UKE, Warszawa 2012. 